\title{
The importance of microbial mats for dolomite formation in the Dohat Faishakh sabkha, Qatar
}

\author{
Marisa Brauchli ${ }^{1} \cdot$ Judith A. McKenzie $^{2}$ - Christian J. Strohmenger ${ }^{3}$. \\ Fadhil Sadooni $^{4}$ - Crisógono Vasconcelos ${ }^{2}$ Tomaso R. R. Bontognali ${ }^{2}$
}

Accepted: 6 September 2015/Published online: 24 September 2015

(C) Springer-Verlag Berlin Heidelberg 2015

\begin{abstract}
The Dohat Faishakh sabkha in Qatar is one of the rare modern environments where it is possible to study the formation of dolomite, a mineral whose origin has been long debated. In previous studies, dolomite formation in this area was considered to be the result of a penecontemporaneous replacement of aragonite, occurring in the presence of Mg-rich evaporated pore-waters. However, a re-investigation of the sabkha revealed that dolomite is not forming exclusively under the evaporitic conditions that characterize the supratidal zone, but also in microbial mats that colonize the lower intertidal zone, indicating that evaporated pore-waters are not a strict requirement for the mineralization process. Moreover, in the supratidal zone, portions of the sediment that are rich in dolomite are also relatively richer in organic material, which derives from partially degraded microbial mats buried in the sediments. Extracellular polymeric substances (EPS) that constitute microbial mats are recognized as an important component for the formation of $\mathrm{Mg}$-rich carbonates. The presence of living and decaying microbial mats comprising EPS, rather than a replacement process, may be the key factor for dolomite formation in the Dohat Faishakh sabkha.
\end{abstract}

Keywords Dolomite $\cdot$ Microbial mat - Exopolymeric substances · Biomineral $\cdot$ Evaporites $\cdot$ Sabkha

Tomaso R. R. Bontognali

tomaso.bontognali@erdw.ethz.ch

1 Institute of Evolutionary Biology and Environmental Studies, University of Zurich, Zurich, Switzerland

2 ETH Zürich, Geologisches Institut, Zurich, Switzerland

3 ExxonMobil Research Qatar, P.O. Box 22500, Doha, Qatar

4 Qatar Research Office, Qatar University, P.O. Box 2713, Doha, Qatar

\section{Introduction}

The origin of sedimentary dolomite - a mineral that is very common in ancient sedimentary rocks but that is difficult to form at low temperatures in laboratory experiments-remains a highly debated subject in the field of sedimentology, which is often referred to as "the dolomite problem" (McKenzie 1991; Warren 2000; Zenger et al. 1980). Research conducted in recent years has demonstrated that microbes can mediate dolomite formation at low temperatures, providing a possible solution to this conundrum (McKenzie and Vasconcelos 2009). Early geobiological studies proposed that microbial respiration is an important factor for the formation of dolomite (Vasconcelos et al. 1995; Warthmann et al. 2000; Wright and Wacey 2005), while the results of more recent research evidenced that extracellular polymeric substances (EPS) likely play the key role for the mineralization process (Bontognali et al. 2010, 2014; Krause et al. 2012; Paulo and Dittrich 2013; Roberts et al. 2013). EPS is a wide term that refers to all organic molecules that microbes excrete from the cell to their surrounding environments, and that constitute most of the biomass of microbial mats (Decho 1990; Dupraz et al. 2009). Although the exact mechanism governing this microbially influenced mineralization process is not fully resolved, it has been demonstrated that the presence of EPS favors the incorporation of $\mathrm{Mg}$ into the carbonate mineral, leading to the formation of dolomite (Bontognali et al. 2010; Lenders et al. 2011; Roberts et al. 2013). Recent studies of the coastal sabkha of Abu Dhabi have shown that microbial mats and associated EPS are important for dolomite formation also in extreme evaporitic environments, which may initially appear inhospitable to life and dominated by purely physical and chemical processes (Bontognali et al. 2010; Sadooni et al. 2010). 
The goal of this study was to evaluate whether microbial mats and their EPS play a role for dolomite formation also in the Dohat Faishakh sabkha, Qatar (Fig. 1). This sabkha was one of the first evaporitic environments to be studied as a modern analogue for understanding the origin of sedimentary dolomite and its association with other evaporitic minerals (Illing et al. 1965; Wells 1962). The concepts and hypotheses deriving from these pioneer studies become very influential in the field of sedimentology. Dolomite formation in this area was considered to be the result of a penecontemporaneous replacement of aragonite, driven by evaporation that leads to precipitation of gypsum with consequent increase of pore-water's $\mathrm{Mg} / \mathrm{Ca}$ ratio (Illing and Taylor 1993; Illing et al. 1965). However, no conclusive petrographic and microscopic evidence confirmed this hypothesis, and such a replacement process was never successfully simulated at low temperature in laboratory experiments.

To test the hypothesis that a "microbial factor", rather than a replacement process, is important in this evaporitic environment, core samples and microbial mats were collected along a transect from the lower intertidal to the supratidal zone of the Dohat Faishakh sabkha (Fig. 1c), from approximately the same location originally studied by Illing and his colleagues. The collected material was subsequently used for conducting sedimentological, mineralogical, and microscopic investigations.

\section{Study area and methods}

The sabkha Dohat Faishakh sabkha (Fig. 1), on the western coast of the Qatar peninsula, is an evaporitic environment mainly comprising carbonate minerals that formed during the Holocene (after an highstand that occurred approximately 4000-6000 years ago) by progradation of subaqueous, intertidal and supratidal sediments. Detailed information about the geology and the environmental conditions characterizing the sabkha are reported in Illing et al. (1965), Jameson et al. (2009), Whitaker et al. (2014) and Puls et al. (2009). The exact coordinates where the samples used for this study were collected are: Core DF1 $\left(25^{\circ} 38^{\prime} 00.8^{\prime \prime} \mathrm{N}\right.$; $\left.050^{\circ} 56^{\prime} 52.4^{\prime \prime} \mathrm{E}\right)$, Core DF2 $\left(25^{\circ} 37^{\prime} 55.7^{\prime \prime} \mathrm{N}\right.$; $\left.050^{\circ} 56^{\prime} 51.8^{\prime \prime} \mathrm{E}\right)$, Core DF3 $\left(25^{\circ} 37^{\prime} 53.9^{\prime \prime} \mathrm{N} ; 050^{\circ} 56^{\prime} 51.3^{\prime \prime} \mathrm{E}\right)$, Core DF4 $\left(25^{\circ} 37^{\prime} 48.8^{\prime \prime} \mathrm{N}\right.$; $\left.050^{\circ} 56^{\prime} 50.7^{\prime \prime} \mathrm{E}\right)$, Core DFa $\left(25^{\circ} 37^{\prime} 48.8^{\prime \prime} \mathrm{N} ; 050^{\circ} 56^{\prime} 50.7^{\prime \prime} \mathrm{E}\right)$.

The bulk mineralogy at different depths of the cores was determined with a powder X-ray diffractometer Bruker AXS D8 Advance (Bruker AXS Inc., Madison, WI, USA), equipped with a Lynxeye superspeed detector.

The total carbon (TC) and the total inorganic carbon (TIC) content of the sediment samples were measured with a CM 5012 CO2 Coulometer (UIC Inc., Joliet, IL, USA)

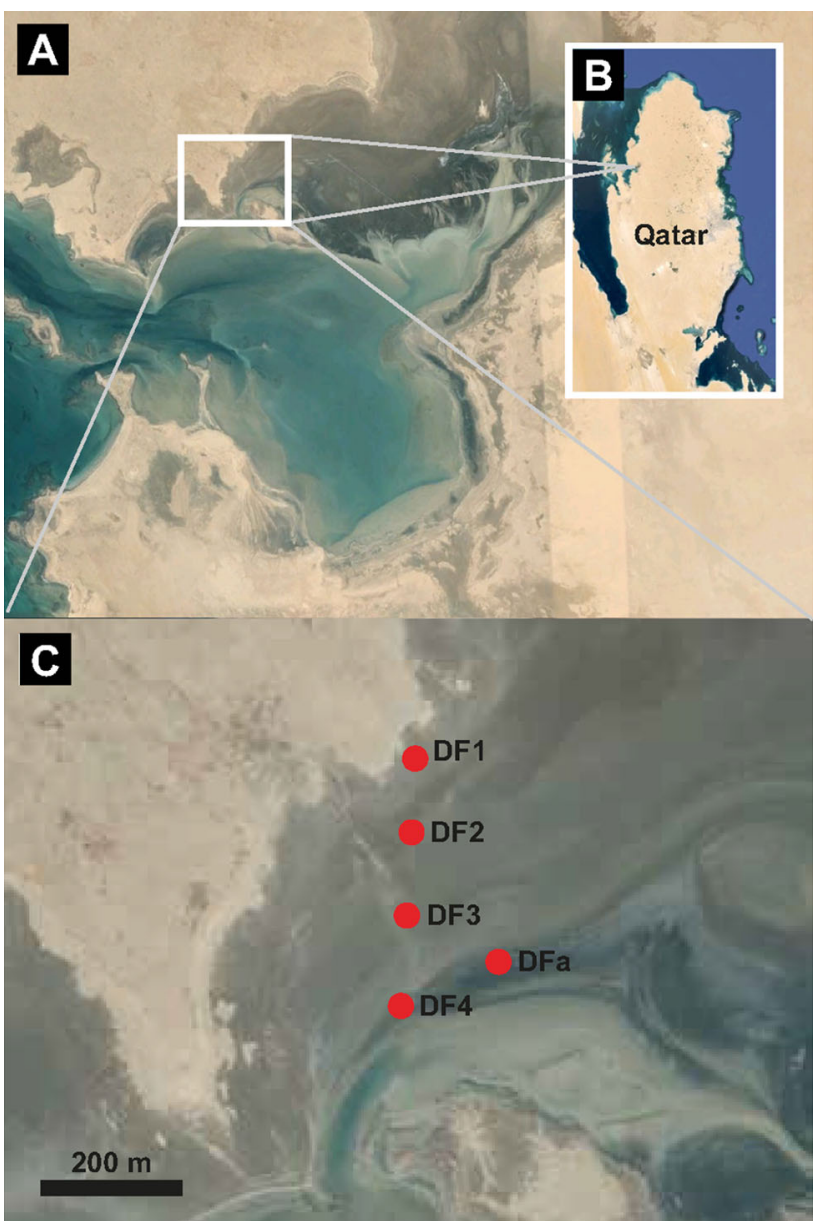

\section{D}

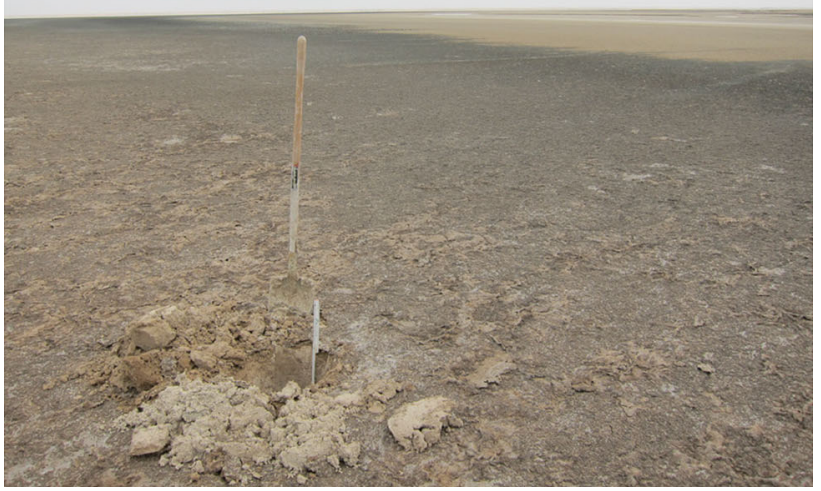

Fig. 1 Study area. a Satellite image of the Dohat Faishakh sabkha. b Position of the studied sabkha on the western coast of Qatar. c Close-up of the region of the sabkha (white rectangle in a) showing the location where the core samples investigated in this study were collected. d Photograph of the intertidal zone of the sabkha, which is colonized by microbial mats (i.e., dark horizon visible in the picture). Satellite images from WorldView-2 Imagery

using a weight of around $20 \mathrm{mg}$ of previously freeze-dried homogenized bulk sample. The accuracy of the carbon measurements is better than $0.1 \%$. 
Scanning electron microscopy analyses were performed with a Zeiss Supra 50 VP (Carl Zeiss AG, Jena, Germany) at the University of Zurich, equipped with an energy-dispersive X-ray detector for element analysis (EDX). In order to avoid precipitation of halite crystals and preserve the organic structures comprising the EPS-which are usually destroyed during the drying procedure necessary to apply the metal coating - the samples were shock-frozen in liquid nitrogen and subsequently freeze-dried.

\section{Results}

The mineralogy of the studied samples corresponds to that described in previous studies of the same region (Illing and Taylor 1993). Muds mainly comprising authigenic aragonite, including variable amount of detrital sands and gastropod shells, dominate sediment present in the lower intertidal zone. At the surface, this mud is fully colonized by microbial mats, which, in earlier studies, were commonly referred to as algal mats (Figs. 1d, 2, 5a). In the upper intertidal zone, these microbial mats are progressively interbedded with fine gypsum crystals. Gypsum dominates the uppermost portion of the sediment throughout the whole supratidal zone, where conditions are too dry to allow the development of microbial mats. Beneath the surface, the sediments of the supratidal zone are composed of a mixture of authigenic carbonate muds (mainly aragonite and dolomite), authigenic gypsum (with crystal bigger than those present at the surface), detrital sands (including abundant gastropod shells), and buried microbial mats. Although some relic laminations are clearly visible, the buried mats in core DF1 appear highly degraded and poorly preserved with respect to mats present at the surface of core DF4 and DFa (Fig. 2b). Progressive degradation of the organic material constituting the mats is also consistent with the total organic carbon (TOC) values measured in the four cores, which progressively decrease landward from core DF4 to core DF1 (Fig. 3). Average dolomite/aragonite ratios show an opposite trend, increasing from the intertidal to the supratidal zone. However, by looking at the vertical profile of the single cores, it is possible to see (except for core DF4) a positive correlation between dolomite/aragonite ratios and TOC concentrations (Fig. 3).

SEM investigations combined with EDX elemental analysis revealed that the dolomite identified with the XRD analysis (Fig. 4) occurs mainly as rhombohedral crystals, which are easily discernible from the needle-like crystals of authigenic aragonite (Fig. 5). In the investigated samples, there was no morphological feature suggesting that dolomite formed by replacement of pre-existing dolomite. In some rare instances, needles of aragonite are engulfed in rhombs of dolomite. However, there is no evidence for a genetic relationship between these two mineral phases, which seem to form independently without producing any hybrid crystal morphology (Fig. 5c).

SEM investigations of living microbial mats (using a preparation method that preserves EPS) showed that dolomite with crystal size and morphology similar to that occurring a depth in the supratidal zone is also present at the surface in the lower intertidal zone (Fig. 5b). In these living microbial mats, it is possible to see the close association between dolomite and an alveolar matrix that comprised the EPS (Fig. 5a). Such prominent organic matrix is no longer visible in the sediments collected from the supratidal zone, where the buried mats are highly degraded (Fig. 5c).

\section{Discussion}

In previous studies of the Dohat Faishakh sabkha, dolomite formation was considered to be a replacement process occurring in the supratidal zone, where precipitation of
Fig. 2 Microbial mats. a Representative sample of a living microbial mat that colonizes the lower intertidal zone of the Dohat Faishakh sabkha. b Uppermost $7 \mathrm{~cm}$ of core DFa showing how the mat is an integral component of the carbonate mud
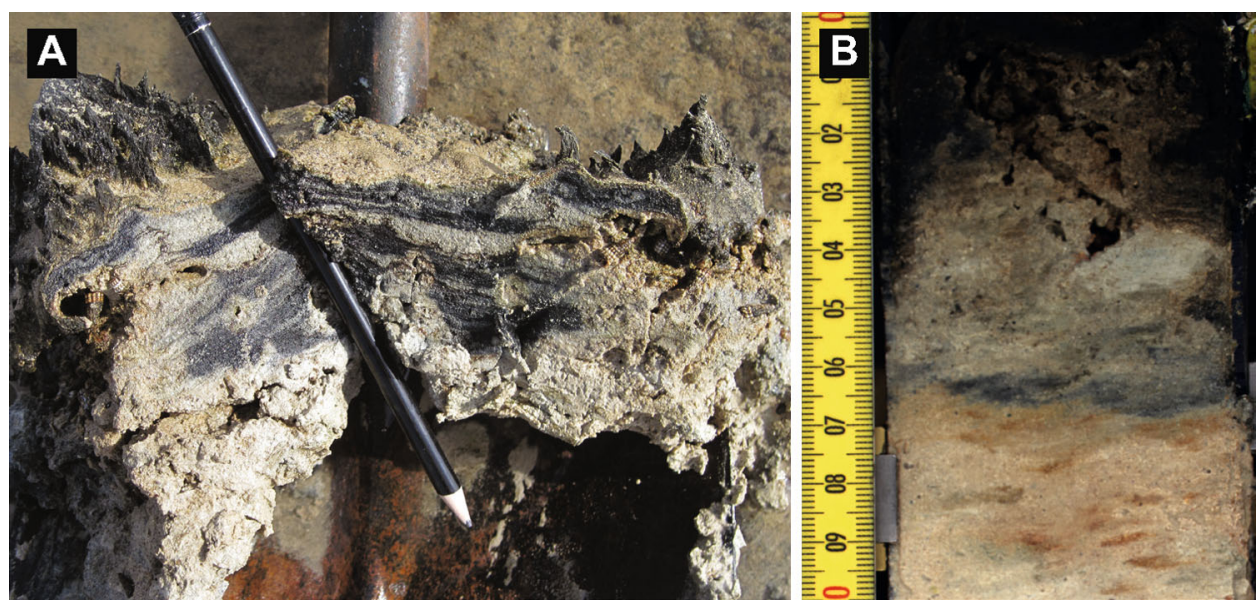


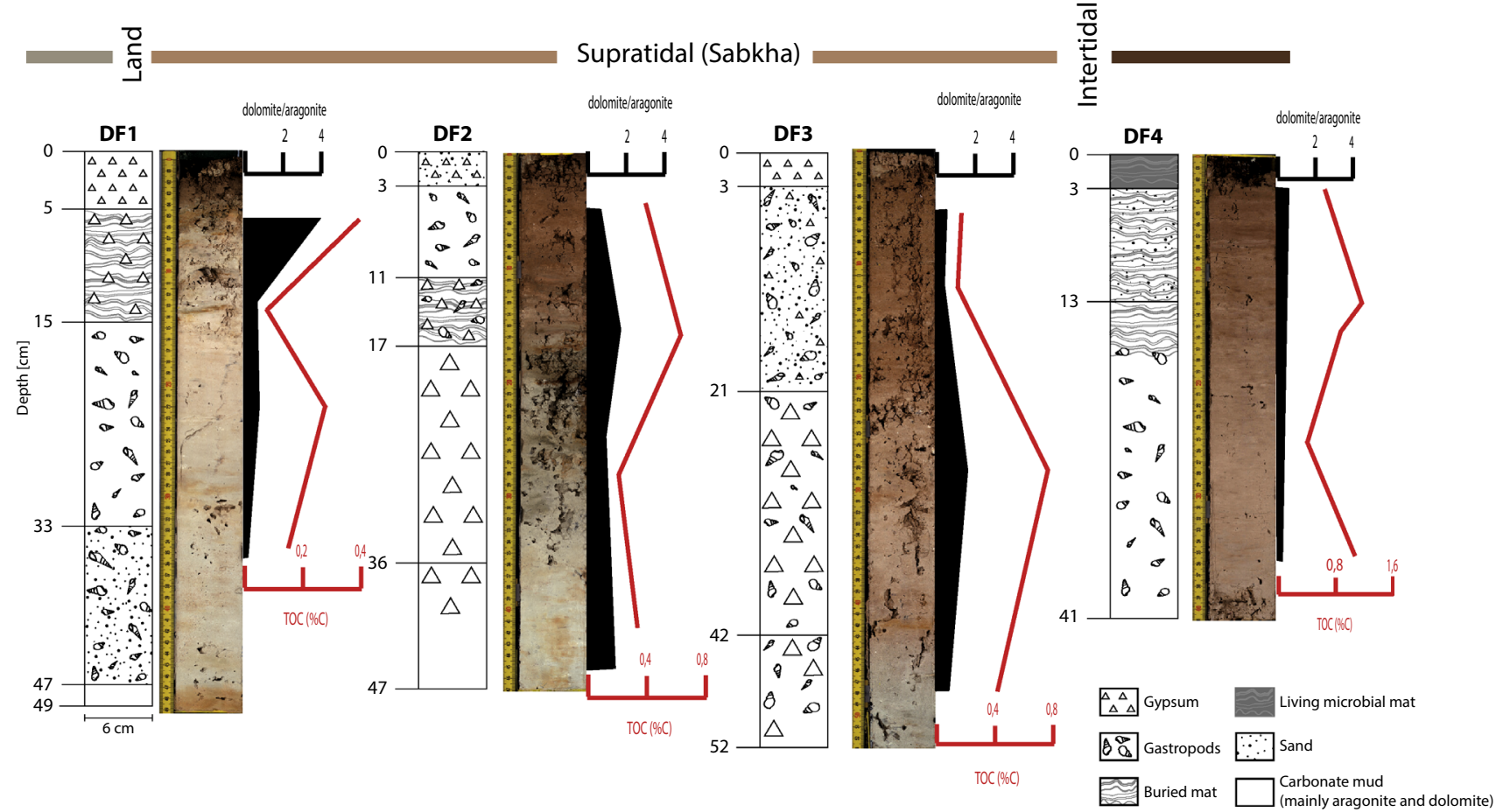

Fig. 3 Photographs of the core samples collected along the studied transect of the sabkha, including a simplified stratigraphy, profiles of total organic carbon (TOC) concentrations, and profiles of dolomite/aragonite ratio

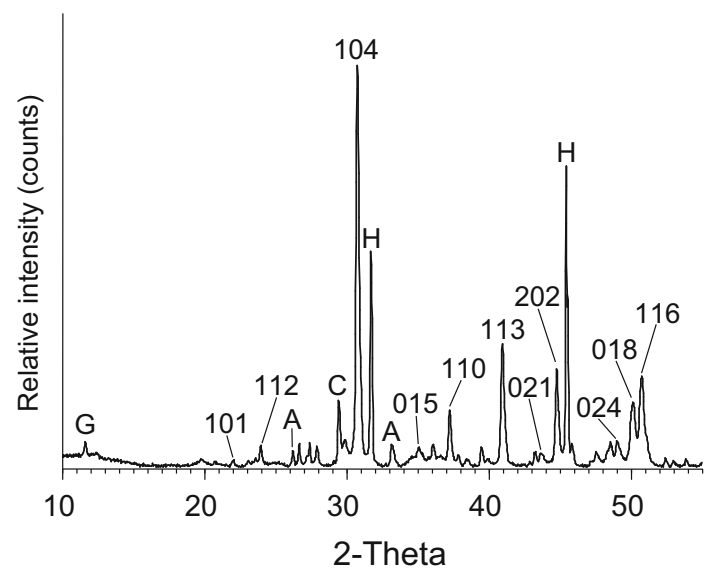

Fig. 4 Representative X-ray diffraction pattern showing the presence of dolomite in the Dohat Faishakh sabkha. The displayed diffraction pattern was obtained by analyzing the bulk sediment of core DF1, at $\sim 6 \mathrm{~cm}$ below the surface (Fig. 3). In the figure, the characteristic reflection peaks of dolomite are labeled with numbers, while the main peaks of other mineral phases constituting the bulk mineralogy are indicated with letters $G$ gypsum, $A$ aragonite, $C$ calcite, $H$ halite. The position of the main 104 dolomite peak-corresponding to a value of $2.90 \AA$ - and the broad shape and slightly leftward-shifted position of the ordering reflections peaks 015 and 021 indicate that dolomite is richer in calcium with respect to a stoichiometric dolomite and not fully ordered

gypsum due to evaporation removed calcium and sulphate, producing a Mg-enriched brine that slowly dolomitizes the predominantly aragonitic sediment (Illing and Taylor 1993;
Illing et al. 1965). This model is compatible with the increasing dolomite/aragonite ratio that, as in this study, was observed along a transect from the lower intertidal zone to the supratidal zone. However, despite the fact that this replacement model can be easily tested with a laboratory experiment, all efforts made in this direction failed (Land 1998). On the contrary, it has been shown that temperatures of at least $80{ }^{\circ} \mathrm{C}$ are required to transform calcite or aragonite into dolomite (Baker and Kastner 1981). It can be excluded that the sediments of the sabkha ever reached this temperature (Jameson et al. 2009). On the other hand, it cannot be excluded that the replacement process occurs on a time scale of thousands of years (Illing and Taylor 1993), a time that is too long to be simulated with laboratory experiments.

The results of this study provide evidence that appears inconsistent with the abovementioned "replacement model", whereas it supports the more recent hypothesis proposing that EPS may be the key factor for dolomite formation in evaporitic environments (Bontognali et al. $2010,2012)$. The presence of dolomite in the microbial mats that colonize the lower intertidal zone (where no significant amount of gypsum is forming) represents a simple but compelling evidence that evaporated $\mathrm{Mg}$-rich brines are not a strict requirement for dolomite formation in the coastal sabkha environment. This observation is consistent with the results of recent laboratory experiments 

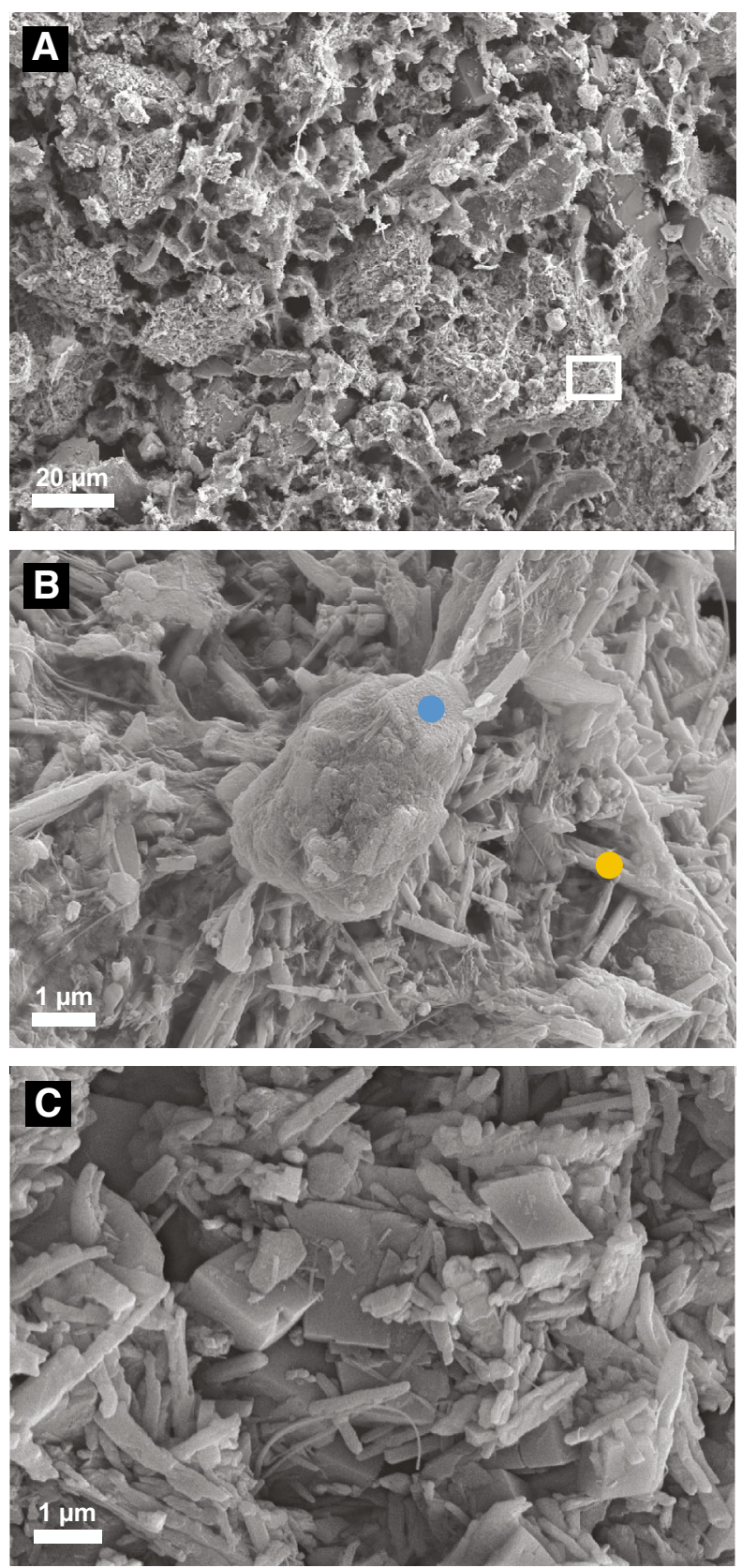

D

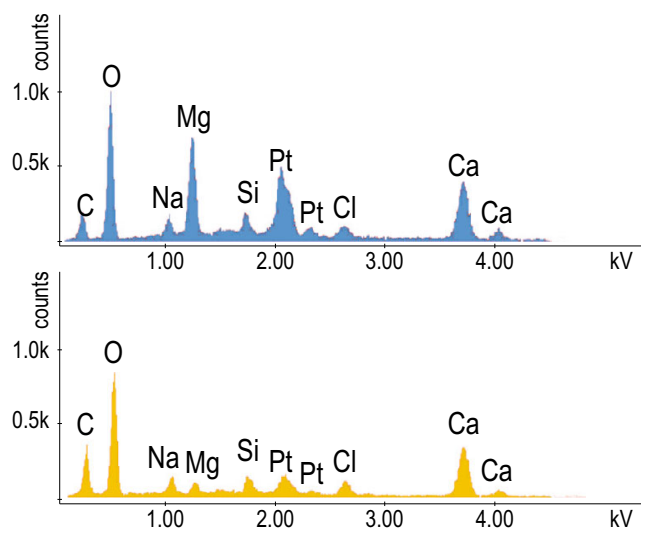

4ig. 5 SEM photomicrographs and EDX analyses. a Overview of the internal section of the microbial mat present at the surface of core DFa (Fig. 2b), which was collected from the lower intertidal zone. The biomass of the microbial mats mainly comprised extracellular polymeric substances (EPS), which form a typical alveolar structure. b Close-up of the EPS matrix (white rectangle in a). The EPS matrix includes aragonite needles (e.g., yellow dot) and rhombohedral dolomite (e.g., blue dot). Note the close association between the dolomite crystals and the partly mineralized EPS (i.e., the amorphous material enveloping the crystals, partly masking their rhombohedral shape). c Sediment present at $-8.5 \mathrm{~cm}$ in core DF1, which was collected from the supratidal zone. Aragonite needles and rhombohedral dolomite with the same morphology and approximately the same size as those shown in the living mats (b) are widespread in the sediment present beneath the surface of the supratidal zone. However, in the supratidal zone, the buried mats are highly degraded and no prominent EPS matrix can be seen in association with the dolomite crystals. No morphological evidence suggests that the aragonite needles are progressively transformed into rhombohedral dolomite. d EDX spectra confirming the dolomitic composition of the rhombohedral crystals (analysis performed on the blue dot visible in b) and the aragonitic composition of the needle-like crystals (yellow dot in panel b). The Pt peak relates to the coating applied during the preparation of the sample, $\mathrm{Na}$ and $\mathrm{Cl}$ peaks relate to halite crystals that formed during sample preparation

showing that dolomite can precipitate from normal (i.e., non-evaporated) seawater, but exclusively in the presence of microbes and EPS (Krause et al. 2012).

The direct correlation between intervals in the cores enriched in organic matter derived from buried microbial mats and likewise enriched in dolomite implies that there is an important relationship between the presence of organic molecules (i.e., EPS) and the mineralization process. Indeed, although the TOC progressively decreases from the lower intertidal to the supratidal zone due to the progressive degradations of the mats, the vertical profiles of TOC show a similar trend to that seen in the profiles of dolomite/ aragonite ratios (Fig. 3).

The progressive degradation of the mats, whose remains are barely visible in the supratidal core DF1, explains why the relationships between microbial mats and dolomite are not necessarily evident in the oldest sabkha sedimentary sections and in ancient sedimentary sequences. The organic molecules comprising the mats are eventually fully degraded and, thus, not preserved in older sediments and ancient rocks, making it impossible to recognize their importance at the time of mineral nucleation and subsequent growth. Perhaps, other geochemical indicators, such as trace organic biomarkers, could be useful fossil signals of the former presence of these important organic molecules.

It is important to note that the microbial mats do no need to be alive and actively metabolizing to mediate dolomite formation. A study of dolomite formation within ancient 
mats buried below the sabkha of Abu Dhabi-an environment that shares many similarities with the Dohat Faishakh sabkha-has shown that dolomite is forming in the supratidal zone within $\sim 900$ years-old, metabolically non-active microbial mats (Bontognali et al. 2010, 2012; Strohmenger et al. 2010, 2011). This is possible because the functional groups present in EPS may continue to influence mineral precipitation long after living microbes have produced them. According to hypotheses derived from laboratory experiments, carboxyl groups that are commonly present in EPS dewater Mg ions promoting its incorporation into the carbonate mineral, which results in dolomite formation at low temperatures. (Bontognali et al. 2014; Roberts et al. 2013; Romanek et al. 2009). A similar process may occur beneath Dohat Faishakh sabkha, where evaporation induces precipitation of carbonate minerals and the presence of the EPS constituting the buried mats influences mineral nucleation, leading to the formation of dolomite.

\section{Conclusion}

The presence of dolomite within the microbial mats of the lower intertidal zone (where the conditions are not highly evaporitic), the lack of hybrid crystals or replacement textures in the sabkha sediments, and the correlation between dolomite and TOC along vertical sedimentary profiles, suggest that dolomite formation in Dohat Faishakh sabkha is not the result of a penecontemporaneous process replacing aragonite, but is rather a microbially influenced mineralization process, whereby specific organic molecules constituting both living and decaying microbial mats promote the incorporation of $\mathrm{Mg}$ into the carbonate minerals.

Acknowledgments We thank Jeremy Jameson for having guided us to the most interesting locations of the Qatari sabkhas, as well as for the numerous stimulating discussions. We also thank ExxonMobil Research Qatar and Qatar University for logistic support during the fieldwork. This study was supported by the Swiss National Science Foundation.

\section{References}

Baker PA, Kastner M (1981) Constraints on the formation of sedimentary dolomite. Science 213:214-216

Bontognali TRR, Vasconcelos C, Warthmann RJ, Bernasconi SM, Dupraz C, Strohmenger CJ, McKenzie JA (2010) Dolomite formation within microbial mats in the coastal sabkha of Abu Dhabi (United Arab Emirates). Sedimentology 57:824-844

Bontognali TRR, Vasconcelos C, Warthmann RJ, Lundberg R, McKenzie JA (2012) Dolomite-mediating bacterium isolated from the sabkha of Abu Dhabi (UAE). Terra Nova 24:248-254

Bontognali TRR, McKenzie JA, Warthmann RJ, Vasconcelos C (2014) Microbially influenced formation of Mg-calcite and Ca- dolomite in the presence of exopolymeric substances produced by sulfate-reducing bacteria. Terra Nova $24: 72-77$

Decho AW (1990) Microbial exopolymer secretions in ocean environments: their role(s) in food webs and marine processes. Oceanogr Mar Biol Annu Rev 28:73-153

Dupraz C, Reid RP, Braissant O, Decho AW, Norman RS, Visscher PT (2009) Processes of carbonate precipitation in modern microbial mats. Earth Sci Rev 96:141-162

Illing LV, Taylor JCM (1993) Penecontemporaneous dolomitization in Sabkha Faishakh, Qatar; evidence from changes in the chemistry of the interstitial brines. J Sediment Res 63:1042-1048

Illing LV, Wells AJ, Taylor JCM (1965) Penecontemporary dolomite in the Persian Gulg. In: Pray LC, Murray LC (eds) Dolomitization and limestone diagenesis, SEPM special publication 13, pp. 89-111

Jameson J, Puls D, Kozar MG (2009) Holocene sabkha and coastal systems of Qatar: process models for the interpretation of ancient Arabian Plate carbonate-evaporite reservoirs. In: International petroleum technology conference

Krause S, Liebetrau V, Gorb SN, Sánchez-Román M, McKenzie JA, Treude T (2012) Microbial nucleation of Mg-rich dolomite in exopolymeric substances (EPS) under anoxic modern seawater salinity: new insight into an old enigma. Geology 40:587-590

Land LS (1998) Failure to precipitate dolomite at $25^{\circ} \mathrm{C}$ from dilute solution despite 1000 -fold oversaturation after 32 years. Aquat Geochem 4:361-368

Lenders JJM, Dey A, Bomans PHH, Spielmann J, Hendrix MMRM, de With G, Meldrum FC, Harder S, Sommerdijk NAJM (2011) High-magnesian calcite mesocrystals: a coordination chemistry approach. J Am Chem Soc 134:1367-1373

McKenzie JA (1991) The dolomite problem: an outstanding controversy. In: Müller DW, McKenzie JA, Weissert H (eds) Controversies in modern geology: evolution of geological theories in sedimentology. Academic Press, London, pp 37-54

McKenzie JA, Vasconcelos C (2009) Dolomite Mountains and the origin of the dolomite rock of which they mainly consist: historical developments and new perspectives. Sedimentology 56:205-219

Paulo C, Dittrich M (2013) 2D Raman spectroscopy study of dolomite and cyanobacterial extracellular polymeric substances from Khor Al-Adaid sabkha (Qatar). J Raman Spectrosc 44:1563-1569

Puls D, Jameson J, Kozar M, Al-Ansi H. LeBlanc J (2009) The Dukhan sabkha: A modern analogue for the arab carbonate reservoir Dukhan Field Qatar. In: International petroleum technology conference

Roberts JA, Kenward PA, Fowle DA, Goldstein RH, Gonzalez LA, Moore DS (2013) Surface chemistry allows for abiotic precipitation of dolomite at low temperature. Proc Natl Acad Sci USA 110:14540-14545

Romanek CS, Jiménez-López C, Navarro AR, Sánchez-Román M, Sahai N, Coleman M (2009) Inorganic synthesis of $\mathrm{Fe}-\mathrm{Ca}-\mathrm{Mg}$ carbonates at low temperature. Geochim Cosmochim Acta 73:5361-5376

Sadooni FN, Howari F, El-Saiy A (2010) Microbial dolomites from carbonate-evaporite sediments of the coastal sabkha of Abu Dhabi and their exploration implications. J Pet Geol 33:289-298

Strohmenger CJ, Al-Mansoori A, Al-Jeelani O, Al-Shamry A, AlHosani I, Al-Mehsin K, Shebl H (2010) The sabkha sequence at Mussafah Channel (Abu Dhabi, United Arab Emirates): facies stacking patterns, microbial-mediated dolomite and evaporite overprint. Geoarabia 15:49-90

Strohmenger CJ, Shebl H, Al-Mansoori A, Al-Mehsin K, Al-Jeelani O, Al-Hoseni I, Al-Shamry A, Al-Baker S (2011) Facies stacking patterns in a modern arid environment: a casa study of the Abu Dhabi sabkha in the vicinity of Al-Qanatir Island, United Arab 
Emirates. In: Kendall CGSC, Alsharhan AS (eds) Quaternary carbonate and evaporite sedimentary facies and their ancient analogues: a tribute to Douglas James Shearman, vol 43, pp 149-182. Wiley-Blackwell, Chichester

Vasconcelos C, McKenzie JA, Bernasconi S, Grujic D, Tiens AJ (1995) Microbial mediation as a possible mechanism for natural dolomite formation at low temperatures. Nature 377:220-222

Warren J (2000) Dolomite: occurrence, evolution and economically important associations. Earth Sci Rev 52:1-81

Warthmann R, Van Lith Y, Vasconcelos C, McKenzie JA, Karpoff AM (2000) Bacterially induced dolomite precipitation in anoxic culture experiments. Geology 28:1091-1094

Wells AJ (1962) Recent dolomite in the Persian Gulf. Nature 194:274-275
Whitaker FF, Didi-Ooi SM, Jameson J, Strohmenger CJ (2014) Origins of evaporites in a holocene mixed clastic and carbonate coastal sabkha: preliminary hydrological and geochemical data from Mesaieed sabkha Qatar. In: International petroleum technology conference

Wright DT, Wacey D (2005) Precipitation of dolomite using sulphatereducing bacteria from the Coorong Region, South Australia: significance and implications. Sedimentology 52:987-1008

Zenger DH, Dunham JD, Ethington RL (1980) Concepts and models of dolomitization. Society of Economic Paleontologists and Mineralogists, Tulsa, p 320 